\title{
Morphology and host-specificity of the apostome ciliate Vampyrophrya pelagica infecting pelagic copepods in the Seto Inland Sea, Japan
}

\author{
Susumu Ohtsuka ${ }^{1, *}$, Mariko Hora ${ }^{1}$, Toshinobu Suzaki ${ }^{2}$, Mikihiko Arikawa $^{3}$, \\ Gen Omura ${ }^{2}$, Kayoko Yamada ${ }^{1}$ \\ ${ }^{1}$ Takehara Marine Science Station, Setouchi Field Science Center, Graduate School of Biosphere Science, \\ Hiroshima University, 5-8-1 Minato-machi, Takehara, Hiroshima 725-0024, Japan \\ ${ }^{2}$ Department of Biology, Faculty of Science, Kobe University, 1-1 Rokkodai-cho, Nada-ku, Kobe 657-8501, Japan \\ ${ }^{3}$ Graduate School of Human Culture, Nara Women's University, Kitauoyanishi-machi, Nara 630-8506, Japan
}

\begin{abstract}
The morphology and host-specificity of the histophagous apostome ciliate Vampyrophrya pelagica infecting pelagic copepods in the Seto Inland Sea, Japan, were intensively investigated. Four stages were reconfirmed in the life cycle of the ciliate. A mature cell within the phoront bears cilia ready for quick excystation, and unique lamellar structures in the cytoplasm appear to be precursors of food vacuole membranes. These lamellar structures completely disappear in the fully grown trophont. The phoronts were attached to the ventral surface of the copepod prosome or legs, but were almost totally absent on the urosome. The number of phoronts per copepod was up to 43 for the adult female of Paracalanus parvus s.l. Phoront attachment was found irrespective of developmental stage and sex of $P$. parvus s.l., although the early copepodid stages were less frequently infected than the later stages, and the adult female was more intensively infected than the adult male. There was a marked seasonal change in prevalence and host-specificity of the phoronts. From middle summer to early winter, P. parvus s.l., Acartia pacifica, Tortanus forcipatus, Euterpina acutifrons, and Corycaeus affinis were frequently infected, while Oithona spp. and Microsetella norvegica were rarely infected, whereas from late winter to early summer, phoronts were detected only on the large-sized calanoids, Calanus sinicus and Euchaeta plana. This may be explained by a combination of longevity and molting of copepods, turnover time of the apostome life cycle which depends on water temperature, and seasonal changes in the abundance and food selectivity of predatory chaetognaths. Considering the high prevalence of apostome ciliates on not only copepods but also other crustaceans in the world oceans, the ecological influence of these ciliates on marine ecosystems should be re-evaluated.
\end{abstract}

KEY WORDS: Apostome ciliate Vampyrophrya pelagica $\cdot$ Copepod $\cdot$ Parasite $\cdot$ Host $\cdot$ Histophagy Trophodynamics

Resale or republication not permitted without written consent of the publisher

\section{INTRODUCTION}

Pelagic copepods generally play an important role in aquatic food chains as a link between lower and higher trophic levels. They are, in turn, utilized by many symbionts (Steuer 1932, Sewell 1951, Marshall \& Orr 1955, Ho \& Parkins 1985, Cachon \& Cachon 1987, Théodoridès 1989, Shields 1994, Ohtsuka et al. 2000). For example, marine copepods are infected by endo- and ectoparasites such as dinoflagellates, ciliates, platyhelminths, acanthocephalids, nematodes, and crustaceans; some infect copepods as their intermediate or final hosts, while others become parasitoids and consume them. Recent studies have reported that the population dynamics of marine copepods is highly influenced by several endoparasitoid dinoflagellates (Ianora et al. 1987, Kimmerer \& McKinnon 1990). A large number of pennate diatoms and peritrich ciliates 
are epibionts which live exclusively on the copepod body surface (Steuer 1932, Sewell 1951, Hiromi et al. 1985, Nagasawa 1986, Fernandez-Leborans \& TatoPorto 2000).

Apostome ciliates are known to infect a wide variety of marine and freshwater crustaceans including shallow- and deep-water copepods (Chatton \& Lwoff, 1935, Sewell 1951, Kudo 1966, Lindley 1978, Grimes \& Bradbury 1992, Ohtsuka et al. 2003). The complex, unique life cycle of the apostome ciliate Vampyrophrya pelagica (Chatton and Lwoff) on coastal copepods was elucidated by Grimes \& Bradbury (1992). According to them, 4 functionally different stages are recognized in this apostome: phoront (resting stage), trophont (feeding stage), tomont (division stage), and tomite (infective stage). Excystation of the trophont is triggered either by injury to the host (single-host cycle) or by predation by invertebrate predators such as hydrozoans, ctenophores, or chaetognaths on copepods with phoronts (2-host cycle). Chaetognath predation, in particular, was considered important for excystation (Grimes \& Bradbury 1992). After excystation the trophonts enter the wounds and promptly consume copepod tissues. Fully grown trophonts then metamorphose into encysted tomonts for palintomy. Tomites are released from the tomonts and infect new host copepods where they become encysted into phoronts (Chatton \& Lwoff 1935, Grime \& Bradbury 1992). This unique feeding behaviour of the apostome is called histophagy (Grimes \& Bradbury 1992). Because the apostome life cycle was deduced mainly from laboratory experiments, the host-specificity, feeding ecology, and ecological impact in the marine ecosystem of the apostome are still unknown in the field. The apostome is common on the coasts of the USA and France, but little attention has been paid to it in other areas (Bradbury 1996). Since few planktologists were aware at the time of the presence of apostome ciliates on copepods, it is probable that phoronts on Paracalanus spp. and Corycaeus spp. were misinterpreted by Chiba (1956) as the copepods' own eggs.

We have therefore intensively investigated the ecology and cytology of Vampyrophrya pelagica in the Seto Inland Sea, Japan, where the seasonal succession of inlet and coastal copepods is well established with a sporadic intrusion of some oceanic copepods in the autumn (Kado 1957, Hirota 1961, 1979). The present paper deals with morphological observations, attachment sites, prevalence and intensity, seasonal occurrence, and host- and stage-specificity in the apostome ciliate $V$. pelagica in the field. Relationships between the prevalence of $V$. pelagica on copepods and the abundance of a potential copepod-predatory chaetognath are also addressed. Ecological roles of apostomes are briefly discussed.

\section{MATERIALS AND METHODS}

Gross morphology. The predominant copepod Paracalanus parvus (Claus) s.l., to which phoronts of the apostome ciliate Vampyrophrya pelagica were attached, was collected from 2001 to 2003 by towing a small plankton net (diameter $30 \mathrm{~cm}$; mesh size $0.1 \mathrm{~mm}$ ) near the sea surface off Takehara Marine Science Station, Hiroshima University, in the central part of the Seto Inland Sea, Japan ( $\left.34^{\circ} 19.3^{\prime} \mathrm{N}, 132^{\circ} 58.2^{\prime} \mathrm{E}\right)$. We observed that trophonts excysted from the phoronts soon (ca. $20 \mathrm{~min}$ ) after ca. 300 individuals were crushed using fine needles, and that the following metamorphosis (to tomonts and tomites) proceeded within the copepod carcasses. Hence, we easily observed all 4 stages of $V$. pelagica in the laboratory. Crushed $P$. parvus s.l. and phoronts were moved to small petri dishes filled with filtered seawater, and then kept in an incubator at a temperature of about $24^{\circ} \mathrm{C}$. The morphology of cells from the phoront to the tomite stage was observed with a light microscope (LM: Nikon Eclipse E600 equipped with Nikon U-III).

Ultrastructure. Host copepods, mainly the calanoid copepod Paracalanus parvus s.l. and the harpacticoid copepod Euterpina acutifrons (Dana), were collected from the same locality on 27 September 2002. The 4 stages of Vampyrophrya pelagica were also observed by scanning (SEM) and transmission (TEM) electron microscopy. For electron microscopy, each stage of $V$. pelagica was fixed for $10 \mathrm{~min}$ at room temperature in $3 \%$ glutaraldehyde in $0.05 \mathrm{M}$ cacodylate buffer (pH 7.0) with $20 \mu \mathrm{M} \mathrm{MgSO}_{4}$ and $2 \mathrm{mM}$ sucrose, and subsequently post-fixed for $30 \mathrm{~min}$ in $0.5 \%$ buffered osmium tetroxide with $20 \mu \mathrm{M} \mathrm{MgSO}_{4}$ and $2 \mathrm{mM}$ sucrose. Fixed cells were dehydrated in a graded ethanol series. For SEM studies, dehydrated cells were dried in a critical point dryer (Hitachi HCP-2), sputter coated with gold (Hitachi E101), and observed with a scanning electron microscope (Hitachi S-2150). For TEM observations, fixed cells were embedded in Spurr's resin, cut in thin sections with an ultramicrotome (Reichelt Ultracut-S), and stained with $3 \%$ uranyl acetate for 30 min followed by Reynolds' lead citrate stain for $5 \mathrm{~min}$. Sections were examined with a transmission electron microscope (Hitachi H-7100) operated at $75 \mathrm{kV}$.

Attachment sites and abundance of phoronts of Vampyrophrya pelagica on dominant copepod Paracalanus parvus s.l. Twenty adult females of the copepod $P$. parvus s.l. were randomly picked from each original sample collected from September to December 1999 when the prevalence of phoronts on the copepods was $100 \%$. A total of 41 adult male P. parvus s.l. individuals collected from August 1999 to January 2000 were also examined. The distribution and num- 
ber of phoronts on 4 different body divisions of each sex of the copepod were investigated: (1) the cephalosome and the first pedigerous somite; (2) the second and third pedigerous somites; (3) the fourth and fifth pedigerous somites; (4) the urosome. The attachment sites of the phoronts were also examined in other species (see Table 1 for species list).

Prevalence of phoronts of Vampyrophrya pelagica on Paracalanus parvus s.l. copepodids. The presence or absence of phoronts on 5 copepodid stages of $P$. parvus s.l. was examined for 20 randomly chosen individuals of each stage collected on 23 September 1999, when the prevalence of phoronts on the adult female was recorded as $100 \%$.

Seasonal change in abundance of pelagic copepods and chaetognaths. Zooplankters were collected from the same locality as above, once a month from May 1999 to April 2000. A NORPAC net (diameter: $45 \mathrm{~cm}$, mesh size: $0.1 \mathrm{~mm}$ ) with a flow-meter set on the net mouth was towed vertically from the near sea-bottom to the surface. Samples were fixed with $10 \%$ neutralized formalin-seawater immediately after collection. All adult individuals of pelagic copepods and all chaetognaths were counted from the original samples or from split subsamples (up to 1/32) under a stereo microscope (Olympus SZ60) or a compound microscope (Nikon YS2). The numbers were then converted into the number of individuals $\mathrm{m}^{-3}$. Surface water temperature and salinity were simultaneously measured with a salinometer (ABB Kent-Taylor, EIL5005). The settling volume of each sample was measured after $24 \mathrm{~h}$.

Prevalence of phoronts of Vampyrophrya pelagica on copepods. The presence or absence of phoronts on copepods was checked in 100 randomly picked adult female Paracalanus parvus s.l. and in 20 to 25 randomly picked adult male $P$. parvus s.l. from an original or a split sample, in order to calculate the prevalence of the phoronts on each sex. Twenty (to 39) copepods of both sexes of copepods other than P. parvus s.l. and the small-sized Oithona spp. were also examined for $V$. pelagica presence from each sample. If an original sample contained fewer than 20 relevant individuals, all intact individuals were examined. All individuals of both sexes of Oithona spp. were examined from the original or split samples.

\section{RESULTS}

\section{Gross morphology}

Phoronts of Vampyrophrya pelagica (Fig. 1A-E) were oval-shaped, 12.5 to $14.6 \mu \mathrm{m}$ in long axis (average $13.7 \mu \mathrm{m}, \mathrm{N}=5$ ) and 9.6 to $10.8 \mu \mathrm{m}$ in short axis
$(10.4 \mu \mathrm{m}, \mathrm{N}=5)$, with a short stalk of about $5 \mu \mathrm{m}$. Cells in this stage were attached around or on the bases of the cephalic and thoracic appendages on the ventral side of the prosome in most copepods (Fig. 1A), or in some species, on the rami of the legs (Fig. 1C).

Trophonts (Figs. 1E,F \& 2B) hatching from the phoronts within 20 min after host copepods were killed. Early cells were about $16 \times 14 \mu \mathrm{m}$. They swam actively around the exterior of the copepod, and entered its tissues through wounds previously made by crushing. They moved actively within the cuticle, frequently picking at the tissue. Copepod muscles seemed to be preferred to gut tissue (Fig. 2A). Although the cytostome was not easily observed with LM, our preliminary SEM observation of the early trophonts revealed that a large, hollow cytostome (about $10 \mu \mathrm{m}$ in diameter) appeared at the anterior tip. As feeding continued, the cells expanded and became pigmented (see Fig. 2A). Two to $3 \mathrm{~h}$ later, fully grown trophonts (Fig. 1F) of about $52 \times 41 \mu \mathrm{m}$ stopped swimming and rested within the copepod to metamorphose into tomonts (Fig. 2A,C,E). Pairs of actively feeding trophonts were sometimes observed to conjugate (cf. Grimes \& Bradbury 1992) during feeding. Our careful observations with SEM of fully-grown trophonts revealed the diagnostic kinety pattern of Vampyrophrya pelagica (cf. Chatton \& Lwoff 1935, Grimes \& Bradbury 1992). We frequently observed trophonts of $V$. pelagica within the guts and fecal pellets of chaetognaths in the field (Fig. 2B).

Tomonts were formed within the host carcasses, usually attached to the inner wall of the cuticle (Fig. 2E). About $20 \mathrm{~h}$ after resting (Fig. $2 \mathrm{C}$ to E), a tomont finally contained 12 to 20 tomites $(\mathrm{N}=5)$ as a result of palintomy. The size of tomonts was 48.3 to $70.2 \mu \mathrm{m}$ (average $60.6 \mu \mathrm{m}, \mathrm{N}=24$ ) $\times 32.7$ to $59.2 \mu \mathrm{m}$ (average $49.5 \mu \mathrm{m}$, $\mathrm{N}=24$ ). Empty tomont cysts remained within the copepod carcasses.

Tomites were released from an opening of about $13 \mu \mathrm{m}$ diameter on the cyst wall of the tomont about $24 \mathrm{~h}$ after it was formed (Fig. 2D). The tomites were teardrop-shaped, with an elongated cilium as described by Grimes \& Bradbury (1992), and 21.4 to $36.9 \mu \mathrm{m}$ (average $28.5 \mu \mathrm{m}, \mathrm{N}=29$ ) $\times 16.7$ to $23.8 \mu \mathrm{m}$ (average $20.2 \mu \mathrm{m}, \mathrm{N}=29$ ) in size. They moved around within a host carcass in search of an exit before escaping and swimming away. We confirmed the metamorphosis of the tomites into phoronts on the ventral surface of live copepods in the laboratory.

\section{Ultrastructure}

TEM observations revealed that mature phoronts possessed cilia on their cell surface inside the cyst 

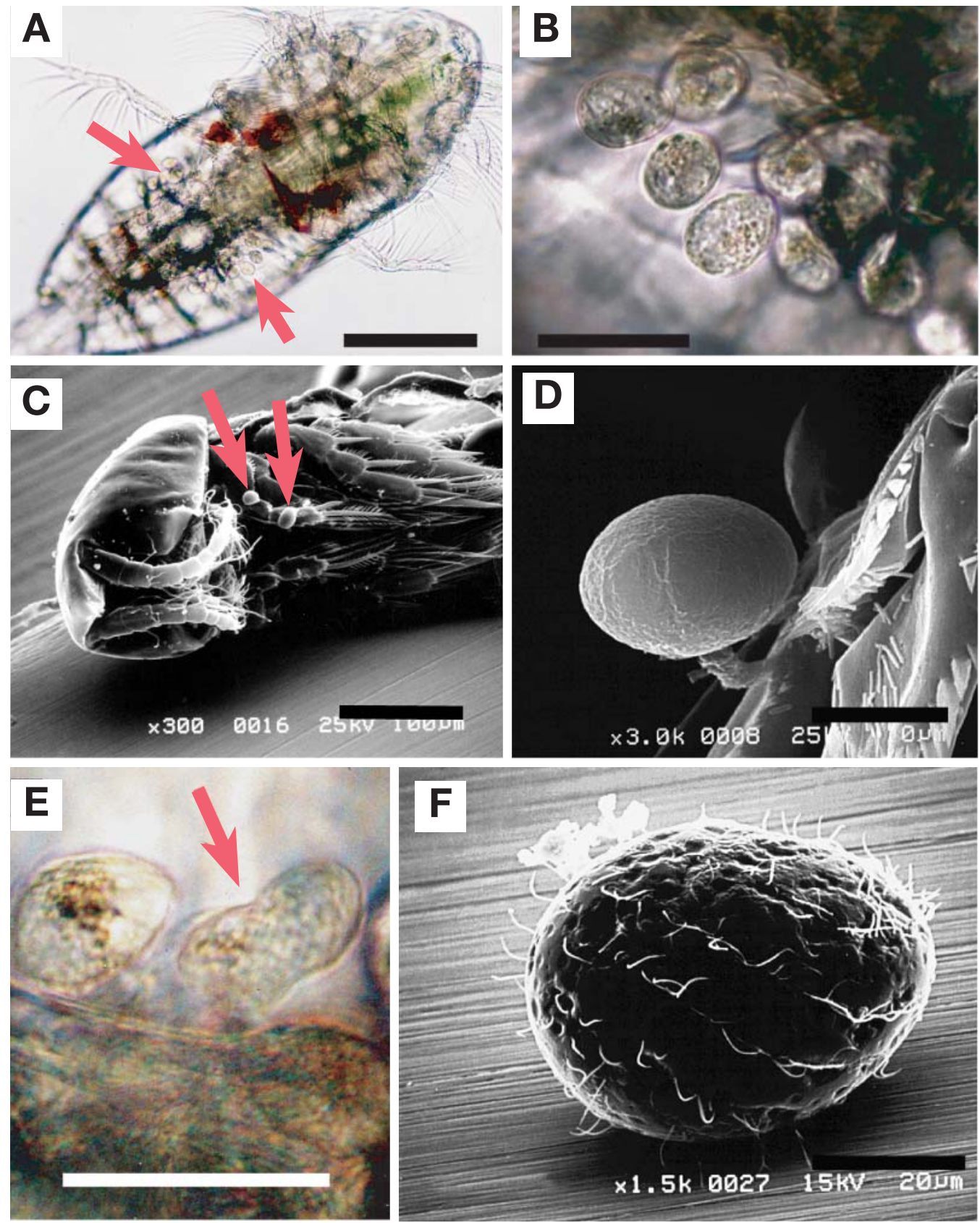

Fig. 1. Vampyrophrya pelagica. (A) Phoronts attached to bases of legs on ventral surface of prosome of Paracalanus parvus s.l. (arrowed). (B) Magnification of phoronts. (C) Phoronts on legs of Euterpina acutifrons (arrowed). (D) SEM micrograph of phoront on E. acutifrons note presence of stalk. (E) Trophont hatching from phoront (arrowed). (F) SEM micrograph of fully grown trophont. Scale bars $=100 \mu \mathrm{m}(\mathrm{A}, \mathrm{C}) ; 20 \mu \mathrm{m}(\mathrm{B}$ F); $10 \mu \mathrm{m}(\mathrm{D}) ; 50 \mu \mathrm{m}(\mathrm{E})$

wall (CL in Fig. 3A,B). This may facilitate their prompt excystation. The cyst wall was composed of an outer thin membrane and an inner thick layer of $0.08 \mu \mathrm{m}$. A large electron-dense granule (? in Fig. 3A) was found in the phoront which may be a residue derived from lipid bodies of the trophont (Fig. 3D). A macronucleus (MA in Fig. 3A) was located in the central part of the cell. Numerous electron-dense lamellar structures of ca. $0.04 \mu \mathrm{m}$ in thickness were present in the cytoplasm (LS in Fig. 3B) and observations of several sections revealed that the lamellar body is disc-shaped and approximately $0.5 \mu \mathrm{m}$ in diameter (asterisks in Fig. 3C).

Fully grown trophonts (Fig. 3D) had an expanded food vacuole (FV in Fig. 3D) that occupied most of the cytoplasm and pushed aside the macronucleus and other organelles. Numerous electron-dense lipid bodies (LB in Fig. 3D) were sparsely distributed in the cytoplasm. These may be precursors of the unknown body in the phoront (Fig. 3A). The lamellar structures seen in the phoront (Fig. 3B) completely disappeared in this stage. 

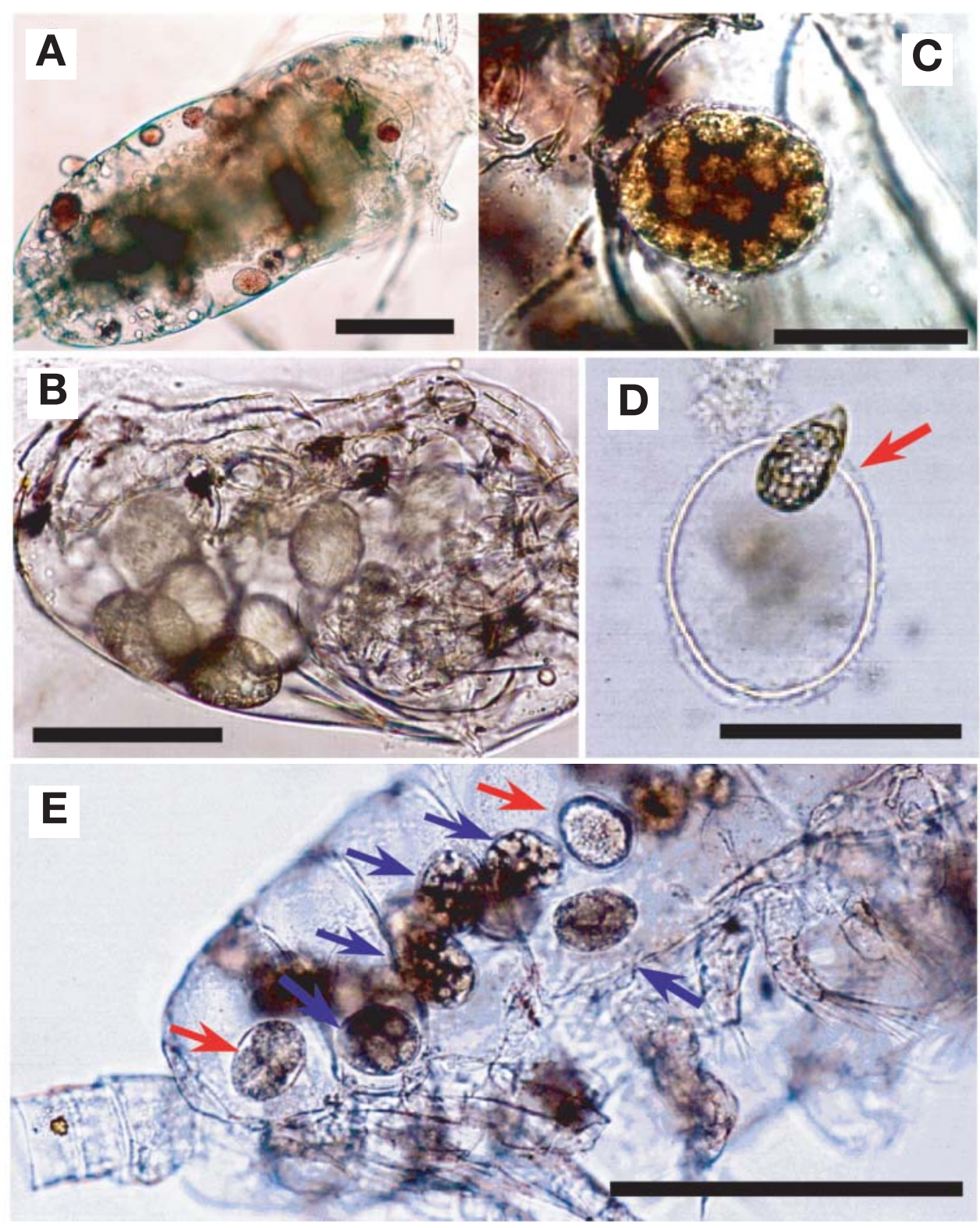

Fig. 2. Vampyrophrya pelagica. (A) Trophonts feeding on tissues of Paracalanus parvus s.l. 160 min after the host was killed. (B) Trophonts within fecal pellet of Sagitta enflata. (C) Tomont in which tomites are already formed. (D) Tomite just hatching from pore of tomont (arrowed). (E) Tomonts of different development stages within carcass of P. parvus s.l. Tomonts indicated by red and blue arrows are early and old stages, respectively. Scale bars $=100 \mu \mathrm{m}(\mathrm{A}, \mathrm{B}) ; 50 \mu \mathrm{m}(\mathrm{C}, \mathrm{D}) ; 200 \mu \mathrm{m}(\mathrm{E})$

\section{Attachment sites and intensity}

Phoronts were usually attached near the bases of the cephalic and thoracic appendages of almost all the calanoid copepods and the poecilostomatoid copepod Corycaeus affinis McMurrichi (see Fig. 1A,B,E). In the harpacticoid copepod Euterpina acutifrons, however, their attachment sites were restricted mainly to the thoracic legs (Fig. 1C,D). In 3 cyclopoids Oithona attenuata Farran, $O$. brevicornis Giesbrecht and $O$. simplex Farran, the phoronts were attached to the thoracic legs, the lateral surface of the urosome or the dorsal and lateral surfaces of the prosome.

In the copepod Paracalanus parvus s.l. the attachment site of the phoronts was usually restricted to near the base of appendages on the ventral surface of the prosome. In the adult female of $P$. parvus s.l. (sampled from September to December 1999) the attachment of phoronts was greatest on the cephalothorax (range 0 to 28 , average 5.2), followed by the second and third pedigerous somites ( 0 to $13,2.2)$, the fourth and fifth pedigerous somites (0 to $8,2.0)$, and the urosome (0). In 


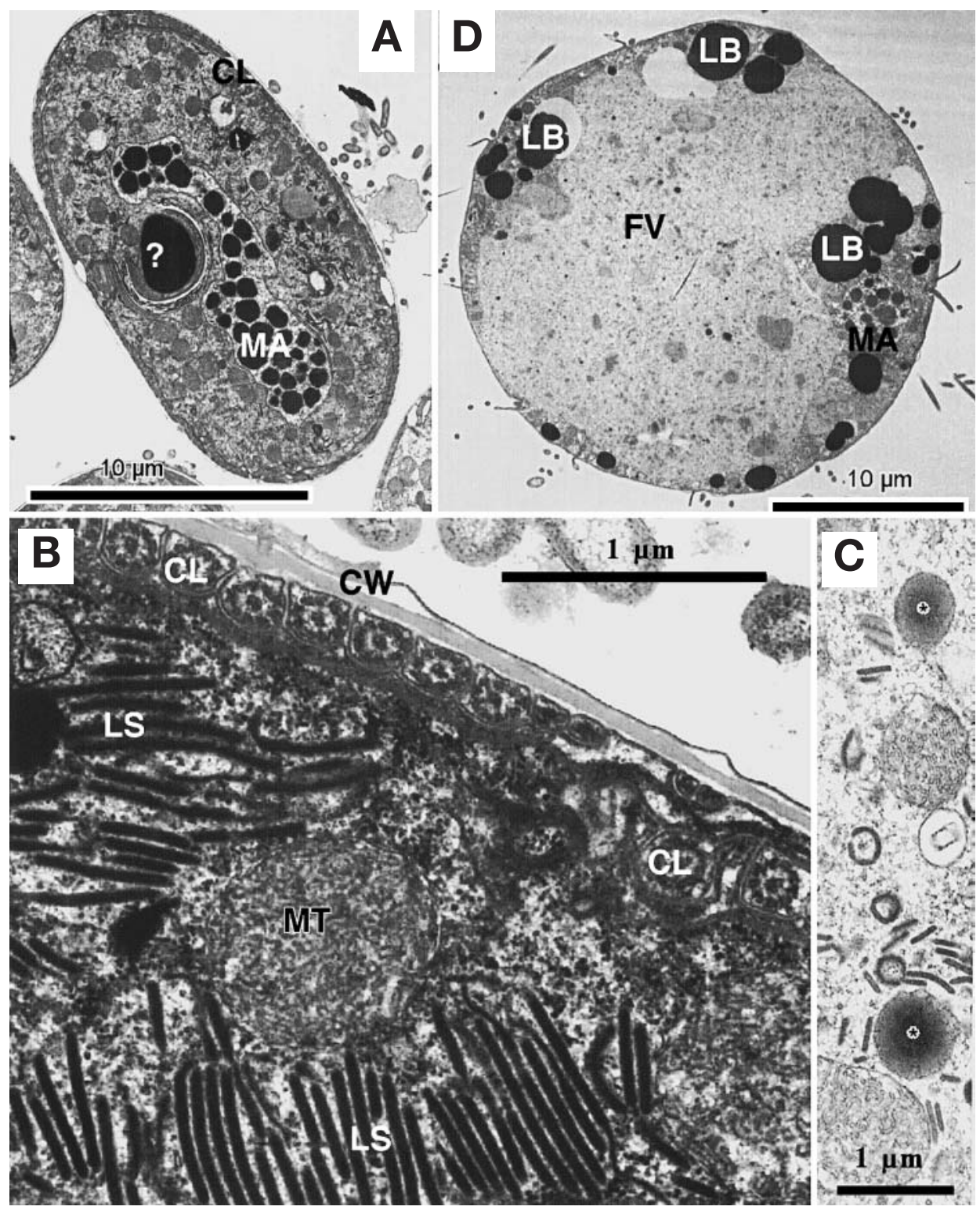

Fig. 3. TEM micrographs of Vampyrophrya pelagica. (A) Phoront. (B) Magnification of phoront showing presence of lamellar structures. (C) Transverse section of lamellar structure (indicated by stars). (D) Fully grown trophont; note absence of lamellar structures. CL: cilium; CW: cyst wall; FV: food vacuole; LB: lipid body; LS: lamellar structure; MA: macronucleus; MT: mitochondoria; ?: possible residue derived from lipid body of trophont

the adult male copepod the numbers of phoronts on the second to fifth pedigerous somites were significantly lower than in the adult female $(t$-test, $\mathrm{p}<0.01)$ : cephalothorax (range 0 to 16 , average 4.4 ); second and third pedigerous somites $(0$ to $7,0.8)$; fourth and fifth pedigerous somites ( 0 to $4,0.5)$; urosome $(0$ to $1,0.0)$.

The number of phoronts per copepod was examined in both sexes of the dominant copepod Paracalanus parvus s.l. In the female it ranged during September, October, November and December 1999 from 3 to 22 (average 9.2), 2 to 18 (8.2), 1 to 43 (9.9), and 2 to 22 (14.1), respectively. In total the range (and average number)of phoronts per adult were: female $(\mathrm{N}=80)$, 1 to 43 (9.3); and male ( $\mathrm{N}=41), 1$ to $17(5.8)$, respectively. The number was significantly higher in the adult female than in the adult male $(t$-test, $\mathrm{p}<0.01)$.

\section{Stage-specificity}

The frequency of occurrence of Vampyrophrya pelagica phoronts on 6 copepodid stages of Paracalanus parvus s.l. was surveyed on 23 September 1999. Although phoronts were attached irrespective of develop- 
mental stage of the host, they generally increased with stage: copepodid I (CI) $55 \%$, CII $90 \%$, CIII 95\%, CIV $100 \%$, CVo $100 \%$, CVơ $85 \%$, CVIo $100 \%$, CVIơ $100 \%$.

\section{Environmental and biological data}

Seasonal changes in surface water temperature and salinity are shown in Fig. 4A. These ranged from 9.9 (24 February 2000) to $26.1^{\circ} \mathrm{C}$ (23 September 1999) and from 30.4 (19 August 1999) to 32.3\%o (13 April 2000), respectively. Settling volume ranged from 0.9 (15 May 1999) to $7.4 \mathrm{ml} \mathrm{m}^{-3}$ (16 July 1999) with 2 peaks in July and December 1999 (Fig. 4B).

Three species of pelagic chaetognath (Sagitta crassa Tokioka, S. enflata Grassi, S. nagae Alvariño) were found in the present study. The dominant species was $S$. crassa, which was collected throughout the year, while the occurrence of the other 2 species was restricted to the period September 1999 to January 2000. The abundance of chaetognaths ranged from 0.5 to 172.7 ind. $\mathrm{m}^{-3}$ (Fig. 4C). The prevalence of the phoronts of Vampyrophrya pelagica on copepods (only species occurring for more than $7 \mathrm{mo}$ ) was not significantly correlated to the abundance of chaetognaths ( $p>0.05$ ), but the highest peak coincided with the rapid increase in the infection of the parasite (see Figs. 5 to 8).

\section{Host-specificity and prevalence}

Adults of 25 species of pelagic copepods were identified in the present study (Table 1: 17 calanoids; 2 harpacticoids, 5 cyclopoids, 1 poecilostomatoid). These copepods can be classified into 3 categories based on their seasonal occurrence: (1) species occurring throughout the year (Paracalanus parvus s.l., Corycaeus affinis, Oithona similis Claus); (2) species appearing mainly in warm seasons (Acartia pacifica Steur, A. erythraea Giesbrecht, Acrocalanus gibber Giesbrecht, A. gracilis Giesbrecht, Centropages tenuiremis Thompson \& Scott, Subeucalanus subcrassus (Giesbrecht), Labidocera rotunda Mori, Paracalanus crassirostris Dahl, Pontellopsis tenuicauda (Giesbrecht), Pseudodiaptomus marinus Sato, Tortanus forcipatus (Giesbrecht), T. gracilis (Brady), Euterpina acutifrons, Oithona davisae Ferrari \& Orsi, O. simplex, O. brevicornis, O. attenuata); (3) species found mainly in cold seasons, i.e. Acartia omorii Bradford, Calanus sinicus Brodsky, Centropages abdominalis Sato, Euchaeta plana Mori, Microsetella norvegica (Boeck). Seasonal changes in copepod abundance and frequency of occurrence of phoronts of Vampyrophrya pelagica on 16 relatively abundant species are depicted in Figs. 5 to 8.
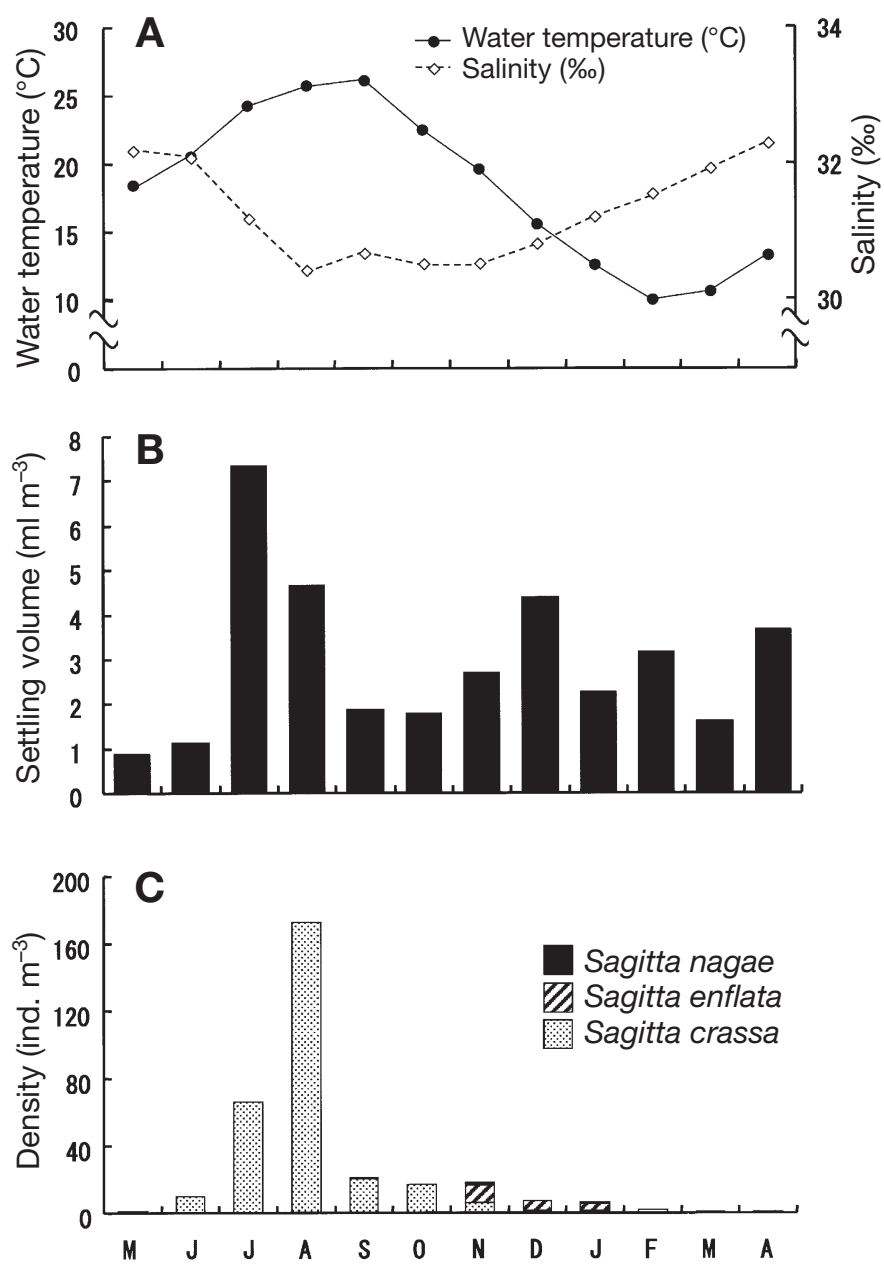

Fig. 4. (A) Seasonal changes in water temperature and salinity; (B) settling volume and (C) abundance of chaetognaths at sampling site in the Seto Inland Sea, Japan

The seasonal patterns in abundance and frequency of occurrence of the phoronts were different in the 3 species that occurred throughout the year. Paracalanus parvus s.l. (Fig. 5A) was the most abundant of the 25 species. The abundance ranged from 19.0 (November) to 704.0 (August) ind. $\mathrm{m}^{-3}$ for the females, and from 7.0 (June) to 85.0 (April) ind. $\mathrm{m}^{-3}$ for the males. The attachment of phoronts showed a remarkable seasonal change (Fig. 5B): in the female, 100\% from September to December, and 0\% from May to July 1999 and in March and April 2000; in the male, 100\% from August to January, and $0 \%$ in May and June 1999, and in March and April 2000.

Corycaeus affinis (Fig. 5C) was abundant in the midwinter to the early summer, ranging from 0.6 (December) to 50.0 (June) ind. $\mathrm{m}^{-3}$ for the females and from 1.1 (December) to 84.8 (June) ind. $\mathrm{m}^{-3}$ for the males. The attachment of phoronts was restricted to the period between August 1999 and January 2000 in the females, and between September and December 1999 
in the males (Fig. 5D); the highest occurrence was recorded in the autumn in both sexes (females, $80 \%$; males, $60 \%$ ).

Oithona similis (Fig. 5E) was abundant in the winter to the early summer, ranging from 0.5 (December) to 106.6 (February) ind. $\mathrm{m}^{-3}$ for the females and from 0 (September, November, December) to 29.1 (June) ind. $\mathrm{m}^{-3}$ for the males. In contrast to the above-mentioned 2 species, no attached phoronts were observed at any time of the year (Fig. 5F).

For the 9 warm-water species the seasonal change in abundance and prevalence of phoronts is shown in Figs. 6 \& 7. Acartia pacifica (Fig. 6A,B) occurred from August to December and phoronts were constantly attached (females, 55.0 to $92.5 \%$; males, 46.2 to $100 \%$ ). The occurrence of Acrocalanus gibber (Fig. 6C,D) was restricted to October to December when phoronts were attached to all individuals of both sexes. Paracalanus crassirostris (Fig. 6E,F) occurred abundantly (females, 388.0 ind. $\mathrm{m}^{-3}$ ) only in November and December, when the attachment of phoronts on the adult female was 36.8 and $40.0 \%$, respectively. A single male of the species collected in December was not infected by Vampyrophrya pelagica. The occurrence of Tortanus forcipatus (Fig. 6G,H) was during the period between June and October. The prevalence of phoronts was constantly high, ranging from 84.0 to $100 \%$ in the female and from 75.0 to $100 \%$ in the male. Euterpina acutifrons (Fig. 6I,J) appeared from August 1999 to February 2000, ranging from 0.4 (February) to 155.3 (September) ind. $\mathrm{m}^{-3}$ for the females, and from 0.5 (March) to 108.7 (September) ind. $\mathrm{m}^{-3}$ for the males. Phoronts were seen from August to January in the female (5.0 to $100 \%$ ) and from August to December in the male (10.0 to $66.7 \%)$. Four species of the cyclopoid genus Oithona (Fig. 7) showed a remarkable difference in the attachment of phoronts. Phoronts were rarely attached in $O$. davisae (female $0.78 \%$ in October, male 0.81 to $0.87 \%$ in August and October), O. simplex (female $2.4 \%$ in October) or O. similis (Fig. 5F). In contrast, females of $O$. brevicornis (3.1 to $33.3 \%$ ) and $O$. attenuata (33.0 to $100 \%$ ) were highly infected, while the males of these 2 species were less frequently infected, $10.0 \%$ at most. The other warm-water species (Acartia erythraea, Acrocalanus gracilis, Centropages tenuiremis, Subeucalanus subcrassus, Labidocera rotunda, Pontellopsis tenuicauda, Pseudodiaptomus marinus, and Tortanus gracilis) were only sporadically collected and all were infected by $V$. pelagica. The attachment of phoronts in these species was restricted to the period from August to November.

For the 4 cold-water species, the seasonal fluctuation in abundance and prevalence of phoronts is depicted in Fig. 8. Occurrence of Acartia omorii (Fig. 8A,B), was restricted from March to July 1999 and January to April
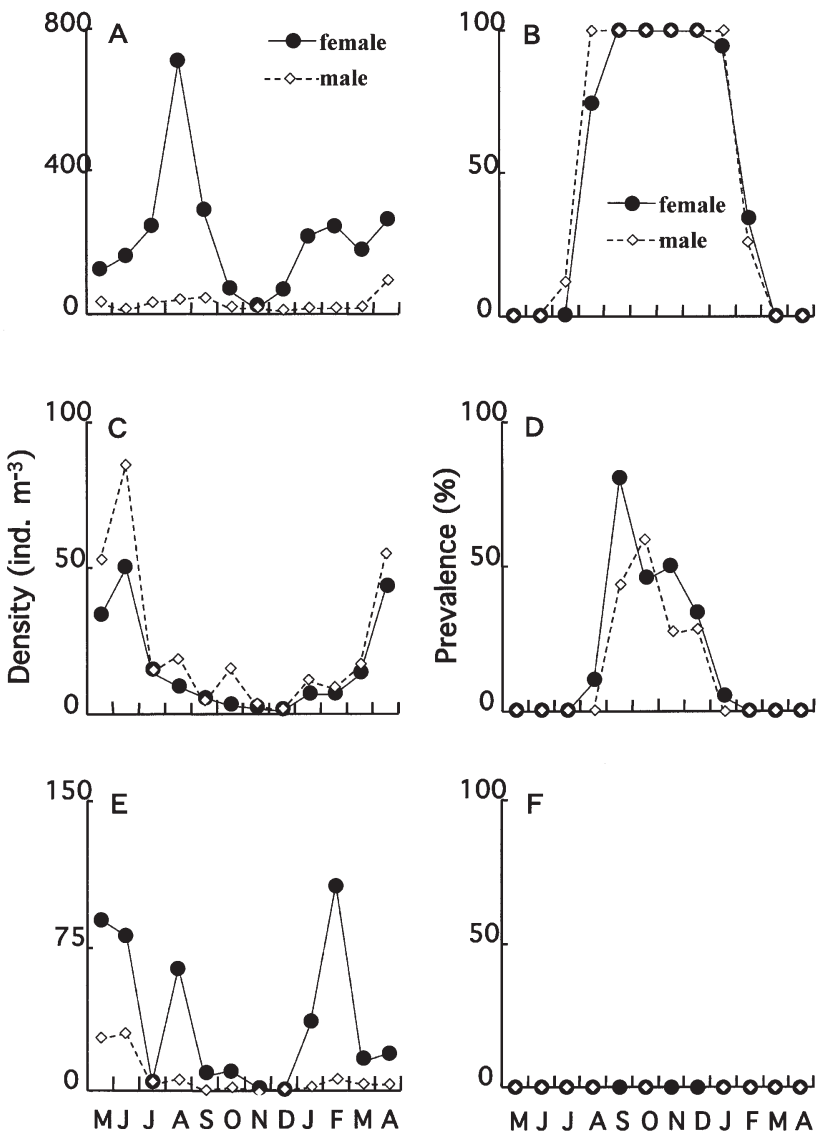

Fig. 5. Seasonal changes in abundance of copepods throughout the year (left) and prevalence of Vampyrophrya pelagica phoronts on the copepods (right). (A, B) Paracalanus parvus s.l.; (C, D) Corycaeus affinis; (E, F) Oithona similis

2000 at relatively low abundance (up to 22.6 ind. $\mathrm{m}^{-3}$ for the females). No attachment of phoronts was seen. Calanus sinicus (Fig. 8C,D) was collected occasionally in July and between January and April, and the attachment of phoronts was frequent (females, 50 to $100 \%$; males, 85.7 to $100 \%$ ). In Centropages abdominalis (Fig. 8E,F) occurrence was restricted to between May and June 1999 and March and April 2000 at low densities (up to 26.0 ind. $\mathrm{m}^{-3}$ for the females). No attachment of phoronts was observed, as in A. omorii (Fig. 8B). Euchaeta plana was very rare, occurring in November 1999 and between January and March 2000. Attachment of phoronts was observed in the adult female in November, January and March, and in the adult male in November and March. For Microsetella norvegica (Fig. 8G,H), occurrence was recorded from October 1999 to April 2000 at relatively low densities (up to 21.3 ind. $\mathrm{m}^{-3}$ in April for both sexes). No attached phoronts were observed.

The host-specificity of Vampyrophrya pelagica was clear, and its prevalence also seemed to show a drastic seasonal change, although attachment of phoronts to some copepods was observed continuously from July 
Table 1. Median body length of adult females of copepods from references, and number of copepods examined from May 1999 to April 2000 for calculation of prevalence. F: female; M: male. Numbers in parentheses are the following sources: (1) Chen \& Zhang (1965); (2) Chen et al. (1974); (3) Nishida (1985); (4) Nishida (1997)

\begin{tabular}{|c|c|c|c|}
\hline Species & Sex & $\begin{array}{l}\text { Median body } \\
\text { length (mm) }\end{array}$ & Number of copepods examined \\
\hline 1. Acartia erythraea & $\begin{array}{l}\mathrm{F} \\
\mathrm{M}\end{array}$ & $1.475(1)$ & $\begin{array}{l}0,0,0,0,14,5,0,0,0,0,0,0 \\
0,0,0,0,14,0,0,0,0,0,0,0\end{array}$ \\
\hline 2. A. omorii & $\begin{array}{l}\mathrm{F} \\
\mathrm{M}\end{array}$ & $0.950(1)$ & $\begin{array}{l}16,20,6,0,0,0,0,0,3,5,14,5 \\
2,20,3,0,0,0,0,0,3,0,8,0\end{array}$ \\
\hline 3. A. pacifica & $\begin{array}{l}\mathrm{F} \\
\mathrm{M}\end{array}$ & $1.275(1)$ & $\begin{array}{l}0,0,0,1,20,20,20,2,0,0,0,0 \\
0,0,0,0,13,10,12,1,0,0,0,0\end{array}$ \\
\hline 4. Acrocalanus gibber & $\begin{array}{l}\mathrm{F} \\
\mathrm{M}\end{array}$ & $1.200(1)$ & $\begin{array}{l}0,0,0,0,0,13,8,2,0,0,0,0 \\
0,0,0,0,0,2,4,0,0,0,0,0\end{array}$ \\
\hline 5. A. gracilis & $\begin{array}{l}\mathrm{F} \\
\mathrm{M}\end{array}$ & $1.125(1)$ & $\begin{array}{l}0,0,0,0,0,0,2,0,0,0,0,0 \\
0,0,0,0,0,0,0,0,0,0,0,0\end{array}$ \\
\hline 6. Calanus sinicus & $\begin{array}{l}\mathrm{F} \\
\mathrm{M}\end{array}$ & $2.700(1)$ & $\begin{array}{l}0,0,2,0,0,0,0,0,6,9,19,7 \\
0,0,0,0,0,0,0,0,1,3,17,3\end{array}$ \\
\hline $\begin{array}{l}\text { 7. Centropages } \\
\text { abdominalis }\end{array}$ & $\begin{array}{l}\mathrm{F} \\
\mathrm{M}\end{array}$ & $1.700(1)$ & $\begin{array}{l}1,2,0,0,0,0,0,0,0,0,1,39 \\
0,0,0,0,0,0,0,0,0,0,0,5\end{array}$ \\
\hline 8. C. tenuiremis & $\begin{array}{l}\mathrm{F} \\
\mathrm{M}\end{array}$ & $1.475(1)$ & $\begin{array}{l}0,0,0,1,3,0,0,0,0,0,0,0 \\
0,0,0,0,1,0,0,0,0,0,0,0\end{array}$ \\
\hline 9. Corycaeus affinis & $\begin{array}{l}\mathrm{F} \\
\mathrm{M}\end{array}$ & $0.810(2)$ & $\begin{array}{l}20,20,20,20,16,11,20,3,20,20,20,4 \\
20,20,20,20,14,20,19,7,20,20,20,10\end{array}$ \\
\hline 10. Euchaeta plana & $\begin{array}{l}\mathrm{F} \\
\mathrm{M}\end{array}$ & $3.375(1)$ & $\begin{array}{l}0,0,0,0,0,0,1,0,1,1,3,0 \\
0,0,0,0,0,0,1,0,0,0,2,0\end{array}$ \\
\hline $\begin{array}{l}\text { 11. Euterpina } \\
\text { acutifrons }\end{array}$ & $\begin{array}{l}\mathrm{F} \\
\mathrm{M}\end{array}$ & $0.705(2)$ & $\begin{array}{l}0,1,1,20,20,20,20,20,20,0,0,0 \\
0,1,1,20,20,20,20,3,4,0,0,0\end{array}$ \\
\hline $\begin{array}{l}\text { 12. Labidocera } \\
\text { rotunda }\end{array}$ & $\begin{array}{l}\mathrm{F} \\
\mathrm{M}\end{array}$ & $2.225(1)$ & $\begin{array}{l}0,0,1,2,1,0,0,0,0,0,0,0 \\
0,0,1,0,0,0,0,0,0,0,0,0\end{array}$ \\
\hline $\begin{array}{l}\text { 13. Microsetella } \\
\text { norvegica }\end{array}$ & $\begin{array}{l}\mathrm{F} \\
\mathrm{M}\end{array}$ & $0.600(2)$ & $\begin{array}{l}0,0,0,0,0,15,16,20,20,20,7,4 \\
0,0,0,0,0,6,9,9,3,4,2,3\end{array}$ \\
\hline $\begin{array}{l}\text { 14. Paracalanus } \\
\text { parvus s.l. }\end{array}$ & $\begin{array}{l}\mathrm{F} \\
\mathrm{M}\end{array}$ & $0.850(1)$ & $\begin{array}{l}100,100,100,100,100,100,100,100,100,100,100,100 \\
6,3,9,1,4,9,11,4,12,8,8,13\end{array}$ \\
\hline 15. P. crassirostris & $\begin{array}{l}\mathrm{F} \\
\mathrm{M}\end{array}$ & $0.590(1)$ & $\begin{array}{l}0,0,0,0,0,0,19,20,5,0,0,0 \\
0,0,0,0,0,0,0,1,0,0,0,0\end{array}$ \\
\hline $\begin{array}{l}\text { 16. Pontellopsis } \\
\text { tenuicauda }\end{array}$ & $\begin{array}{l}\mathrm{F} \\
\mathrm{M}\end{array}$ & $1.650(1)$ & $\begin{array}{l}0,0,0,0,0,0,1,0,0,0,0,0 \\
0,0,0,1,0,0,0,0,0,0,0,0\end{array}$ \\
\hline $\begin{array}{l}\text { 17. Pseudodiaptomus } \\
\text { marinus }\end{array}$ & $\begin{array}{l}\mathrm{F} \\
\mathrm{M}\end{array}$ & $1.350(1)$ & $\begin{array}{l}0,0,0,2,1,0,0,0,0,0,0,0 \\
0,0,0,0,0,0,0,0,0,0,0,0\end{array}$ \\
\hline 18. Oithona attenuata & $\begin{array}{l}\mathrm{F} \\
\mathrm{M}\end{array}$ & $0.790(3)$ & $\begin{array}{l}0,0,0,0,0,23,25,1,0,0,0,0 \\
0,0,0,0,0,10,5,0,0,0,0,0\end{array}$ \\
\hline 19. O. brevicornis & $\begin{array}{l}\mathrm{F} \\
\mathrm{M}\end{array}$ & $0.600(3)$ & $\begin{array}{l}0,0,0,0,0,128,72,6,0,0,0,0 \\
0,0,0,0,0,25,11,5,0,0,0,0\end{array}$ \\
\hline 20. O. davisae & $\begin{array}{l}\mathrm{F} \\
\mathrm{M}\end{array}$ & $0.550(4)$ & $\begin{array}{l}0,5,5,285,32,128,0,0,0,0,0,0 \\
0,3,26,123,144,24,0,0,0,0,0,0\end{array}$ \\
\hline 21. O. similis & $\begin{array}{l}\mathrm{F} \\
\mathrm{M}\end{array}$ & $0.820(3)$ & $\begin{array}{l}187,186,9,95,16,12,3,1,19,15,34,28 \\
55,67,5,8,0,2,0,0,2,12,7,5\end{array}$ \\
\hline 22. O. simplex & $\begin{array}{l}\mathrm{F} \\
\mathrm{M}\end{array}$ & $0.330(3)$ & $\begin{array}{l}0,0,0,0,0,82,36,10,0,0,0,0 \\
0,0,0,0,0,27,8,3,0,0,0,0\end{array}$ \\
\hline $\begin{array}{l}\text { 23. Subeucalanus } \\
\text { subcrassus }\end{array}$ & $\begin{array}{l}\mathrm{F} \\
\mathrm{M}\end{array}$ & $2.150(1)$ & $\begin{array}{l}0,0,0,0,1,1,1,0,0,0,0,0 \\
0,0,0,0,0,0,0,0,0,0,0,0\end{array}$ \\
\hline $\begin{array}{l}\text { 24. Tortanus } \\
\text { forcipatus }\end{array}$ & $\begin{array}{l}\mathrm{F} \\
\mathrm{M}\end{array}$ & $1.300(1)$ & $\begin{array}{l}0,0,3,25,20,4,0,0,0,0,0,0 \\
0,1,1,23,20,4,0,0,0,0,0,0\end{array}$ \\
\hline 25. T. gracilis & $\begin{array}{l}\mathrm{F} \\
\mathrm{M}\end{array}$ & $1.775(1)$ & $\begin{array}{l}0,0,0,0,0,3,0,0,0,0,0,0 \\
0,0,0,0,0,2,1,0,0,0,0,0\end{array}$ \\
\hline
\end{tabular}

1999 to April 2000 (water temperature: 9.9 to $26.1^{\circ} \mathrm{C}$ ). The prevalence of phoronts was significantly correlated to neither water temperature nor the abundance of each copepod ( $p>0.05$ ). In warm seasons all the calanoids and the harpacticoid Euterpina acutifrons were infected by the apostome, whereas in cold seasons its attachment was restricted to relatively large-sized (possibly long-lived) calanoids such as Calanus sinicus and Euchaeta plana. Evidently, no $V$. pelagica was harboured by some species of Oithona and Microsetella norvegica throughout the year. In the cold season, no infection on Acartia omorii and Centropages abdominalis, which are nearly equal in size to the warm-season A. pacifica and C. tenuiremis (Table 1), was observed. Relationships between copepod body length as given in the literature (Table 1) and the prevalence of phoronts are shown in Fig. 9. Significant relationships (Spearman rank correlation) were detected in October $(\mathrm{p}<0.01)$, November 1999 ( $p<0.05)$, January $(\mathrm{p}<0.01)$ and March $2000(\mathrm{p}<0.05)$, suggesting that in cold seasons large-sized long surviving copepods are most likely to be infected.

\section{DISCUSSION}

\section{Morphology}

Phoronts (12.5 to $14.6 \mu \mathrm{m}$ [average $13.7 \mu \mathrm{m}] \times 9.6$ to $10.8 \mu \mathrm{m}[10.4 \mu \mathrm{m}])$ of Vampyrophrya pelagica in the Seto Inland Sea, Japan, were relatively smaller than those (14 to $25 \mu \mathrm{m}$ [19.7 $\mu \mathrm{m}] \times 9$ to $18 \mu \mathrm{m}$ [12.7 $\mu \mathrm{m}])$ in North Carolina, USA, which corresponds to the minimum size of the latter (Grimes \& Bradbury 1992). In mature phoronts it takes 5 to $15 \mathrm{~min}$ to excyst, while in immature ones with oval food plaquettes, more than $1 \mathrm{~h}$ is needed (Grimes \& Bradbury 1992). Our TEM observations of tomites revealed the presence of numerous variable-sized bodies that 

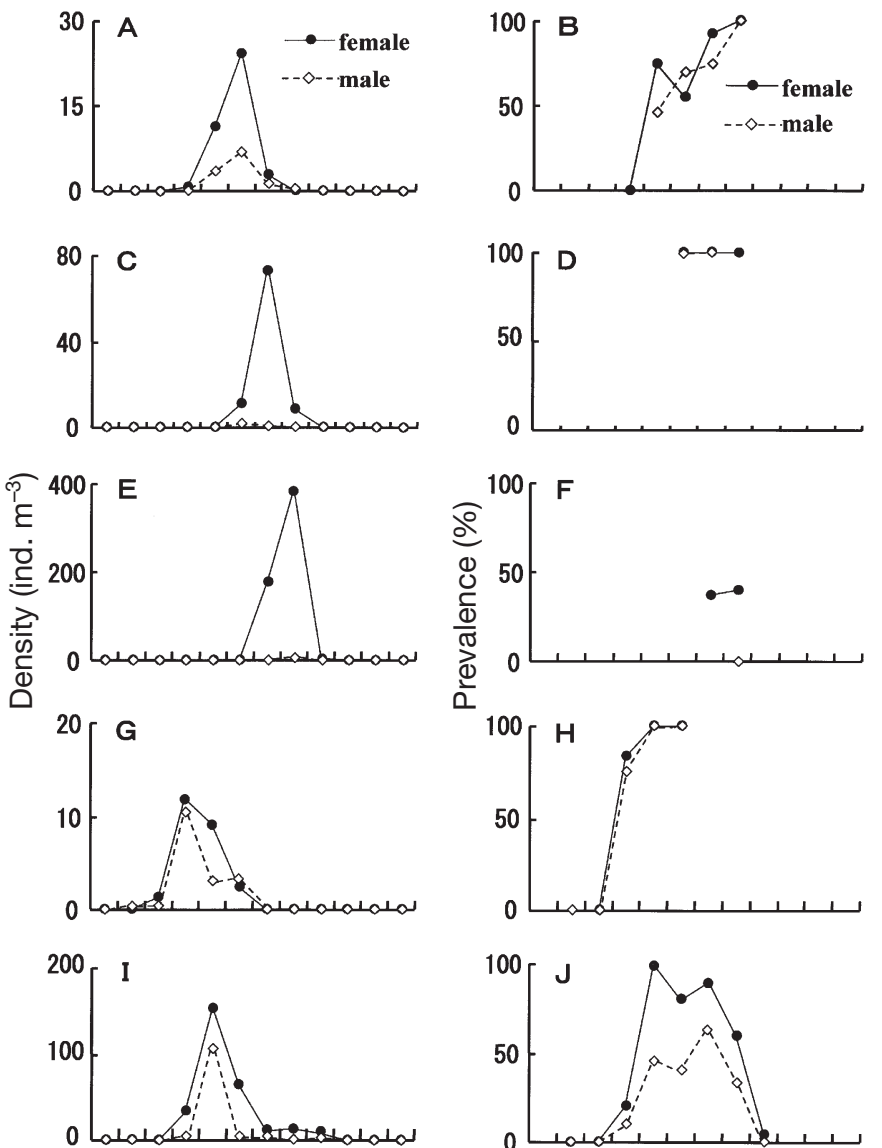

M J J A S O N D J F M A

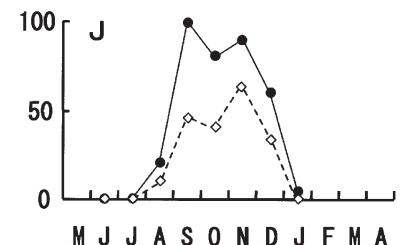

Fig. 6. Seasonal changes in abundance of copepods mainly occurring in summer and autumn (left) and prevalence of Vampyrophrya pelagica phoronts on the copepods (right). (A, B) Acartia pacifica; (C, D) Acrocalanus gibber; (E, F) Paracalanus crassirostris; $(\mathrm{G}, \mathrm{H})$ Tortanus forcipatus; (I, J) Euterpina acutifrons

seem to originate from lipid bodies of the trophont (Suzaki et al. unpubl.). These bodies may correspond to the food plaquettes of Grimes \& Bradbury (1992). As the mature phoront cells contained only one 'lipid' body in the central part (see Fig. 3A), unification of the bodies may have occurred during maturation of the phoront.

The unique lamellar structures are found only in the mature phoront and early trophont stages, and are not observed in the older trophont, tomont or tomite (Suzaki et al. unpubl.). They are sparsely distributed in the cytoplasm in the phoront, but concentrated just under the pellicle and remarkably modified in shape in the early trophont. They totally disappear in the older trophont. These observations suggest that the lamellar structures may be reservoirs of cell membrane used to form a large food vacuole in trophonts. The fully grown trophonts are about 3 to 4 times as large as the initial ones as a result of quick gorging (Grimes \& Bradbury
1992, present study). The rapid growth of the feeding cells may be facilitated by the reservoir of membranous precursors that can be easily incorporated into the rapidly growing food vacuole membrane. The predatory ciliate Didinium nasutum Müller, which feeds on ciliates larger than itself, has structures similar to the lamellar structures of the apostome that have been implicated in its rapid increase in cell volume (Yagiu \& Shigenaka 1965).

The morphology of fully expanded trophonts of Vampyrphrya pelagica reported from North Carolina, USA (configuration of 10 long and 3 short kineties; 50 to $90 \mu \mathrm{m} \times 30$ to $50 \mu \mathrm{m}$ : Chatton \& Lwoff 1935, Grimes \& Bradbury 1992) fits that of the ciliate reported in the present study. Grimes \& Bradbury (1992) observed the ultrastructure of the mature trophonts using TEM. This stage is characterized by the presence of a large food vacuole surrounded by a thin layer of cytoplasm with numerous subpellicular lipid bodies. This was confirmed by our observation. An

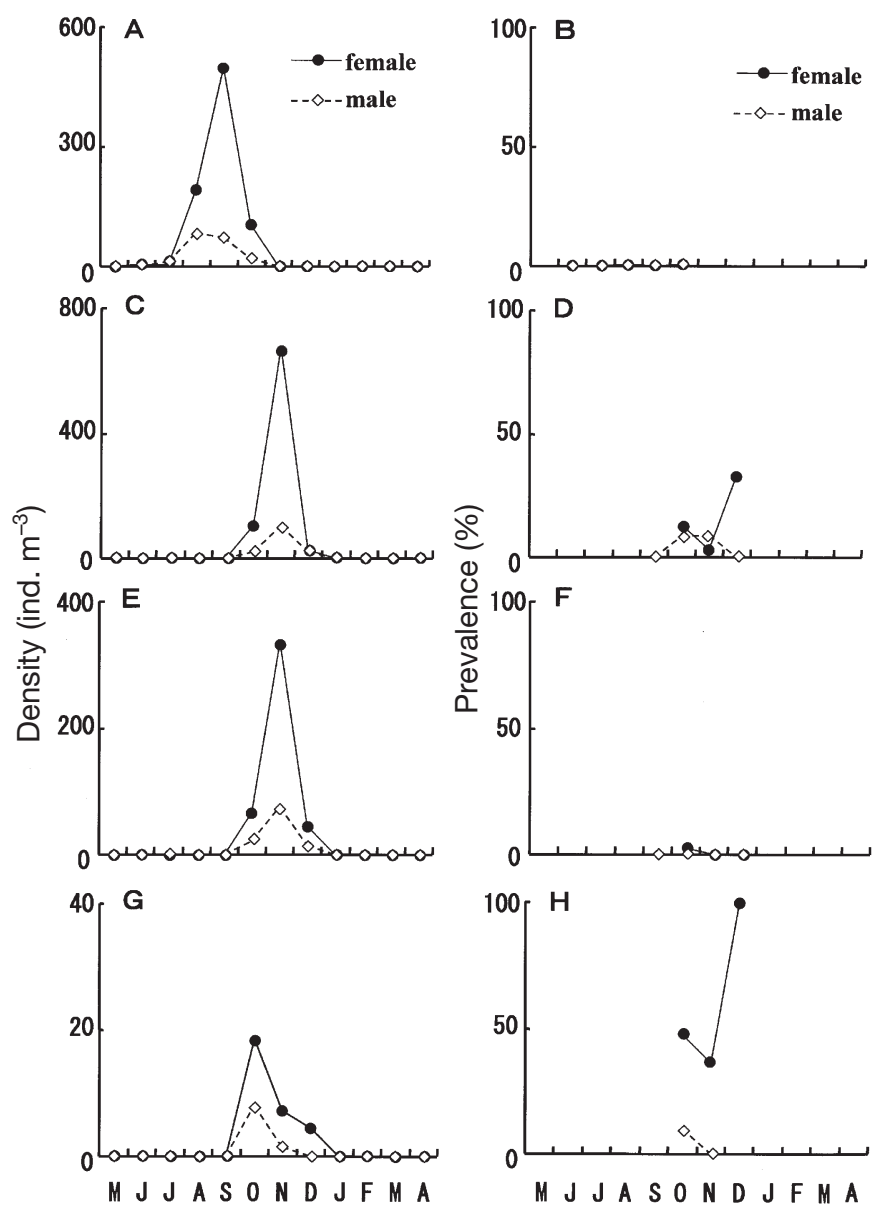

Fig. 7. Seasonal changes in abundance of Oithona spp. mainly occurring in summer and autumn (left) and prevalence of Vampyrophrya pelagica phoronts on the copepods (right). (A, B) Oithona davisae; (C, D) O. brevicornis; (E, F) O. simplex; $(\mathrm{G}, \mathrm{H})$ O. attenuata 

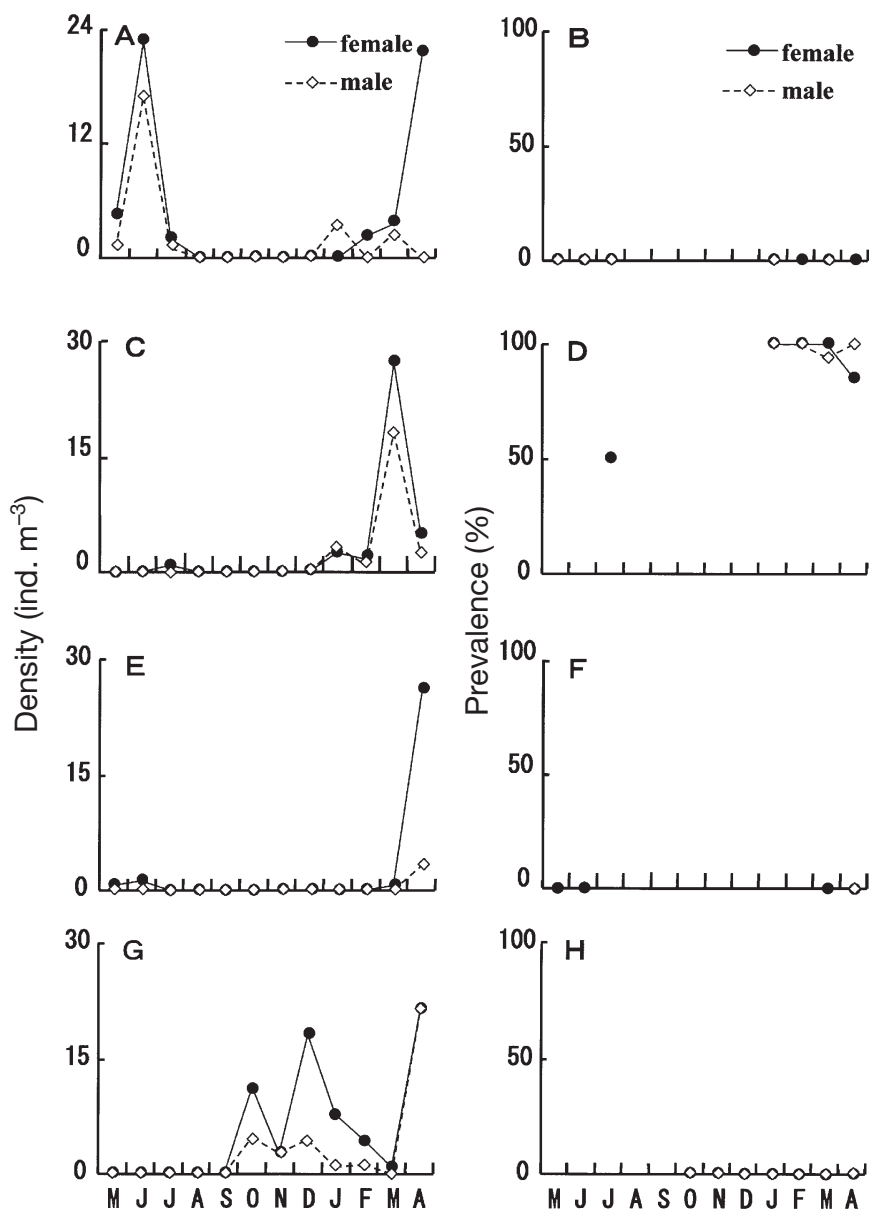

Fig. 8. Seasonal changes in abundance of copepods mainly occurring in winter and spring (left) and prevalence of Vampyrophrya pelagica phoronts on the copepods (right). (A, B) Acartia omorii; (C, D) Calanus sinicus; (E, F) Centropages abdominalis; $(\mathrm{G}, \mathrm{H})$ Microsetella norvegica

electron microscopic observation of apostome cytostomes has been made on Hyalophysa chattoni Bradbury, which is associated with hermit crabs and consumes exuvial fluids remaining in the cast-off cuticles (Bradbury 1966, 1973). However, since V. pelagica seems to ingest fragments of tissues rather than fluids, its feeding apparatus and mechanism may differ from those of H. chattoni. Grimes \& Bradbury (1992) found with LM that the extended cytostome is located between the anterior kineties 1 and 10. Our preliminary observations indicate that the large food vacuole of $V$. pelagica is constructed by invagination of the plasma membrane at the anterior part of the early trophont, not through fusion of small food vacuoles made by pinocytosis.

Tomonts occurring in North Carolina are 34 to $63 \mu \mathrm{m}$ in diameter, and each produces 2 to 32 tomites (Grimes \& Bradbury 1992). The tomonts observed in the present study had a similar size (33 to $59 \mu \mathrm{m} \times 48$ to $70 \mu \mathrm{m})$, and released 12 to 20 tomites. However, the exact number of tomites per tomont should be reexamined considering palintomy. The tomites observed in the present study were larger than those observed by Grimes \& Bradbury (1992) (17 to $23 \mu \mathrm{m} \times$ 21 to $37 \mu \mathrm{m}$ vs. 7 to $11 \mu \mathrm{m} \times 18$ to $20 \mu \mathrm{m})$. The difference may be a geographical variation between the north-western Atlantic and the north-western Pacific.

\section{Life cycle}

We first confirmed that the 4 functionally different stages in Vampyrophrya pelagica are the same in the Seto Inland Sea on the Pacific coast as in the Atlantic (Chatton \& Lwoff 1935, Grimes \& Bradbury 1992). In addition, the dual life cycle of this apostome was also confirmed, although we doubt the attachment of tomites to substrates such as pebbles and the water surface as proposed by Grimes \& Bradbury (1992). We
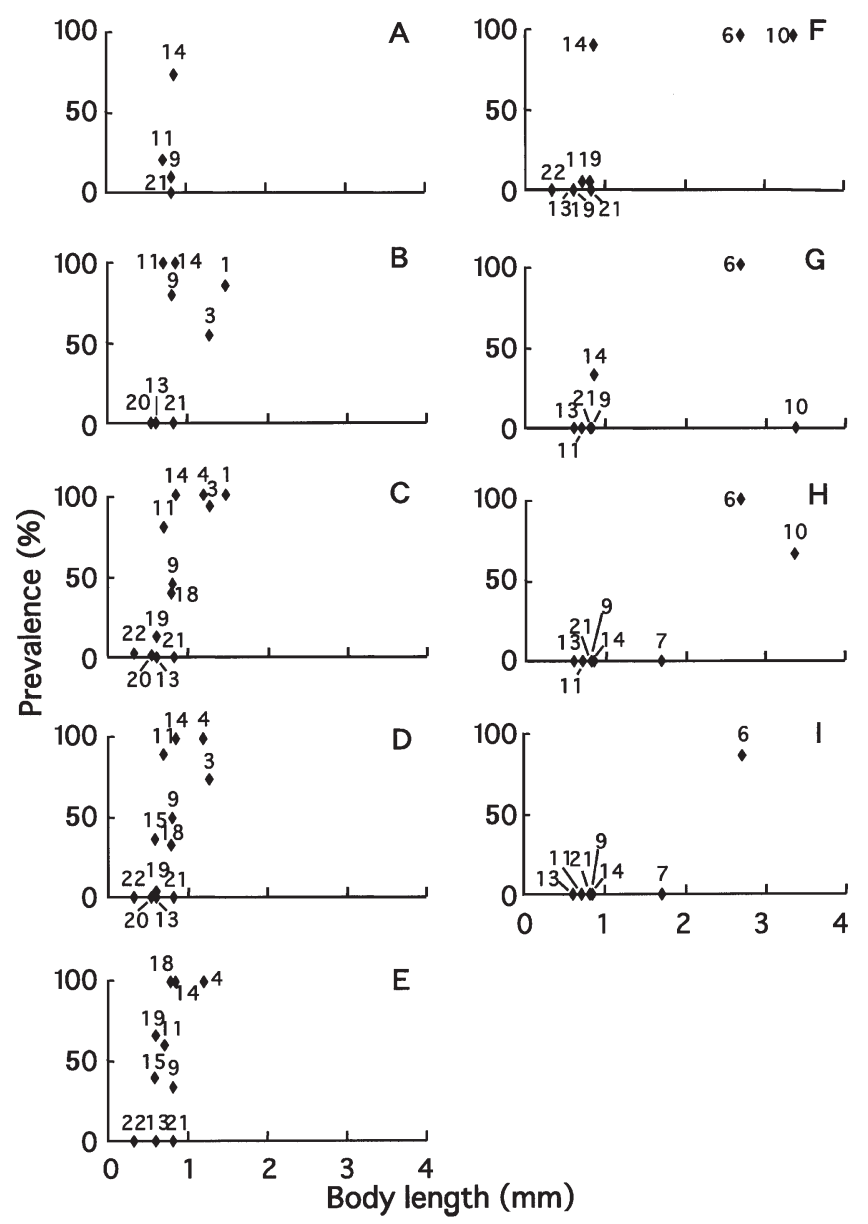

Fig. 9. Relationships between body length of adult female copepods (each species numbered as in Table 1) and prevalence of phoronts on the copepods. (A-I) August 1999 to April 2000. Significant correlation (Spearman correlation rank) found in October $(\mathrm{p}<0.01)$ and November $(\mathrm{p}<0.05) 1999$ and in January $(p<0.01)$ and March $(p<0.05) 2000$ 
have never seen tomites attached to such substrates in the laboratory. In the Seto Inland Sea, we frequently found trophonts in the guts and fecal pellets of chaetognaths that preyed on copepods, but their fate has not been traced yet.

The present study clearly demonstrated the high host-specificity of Vampyrophrya pelagica in the Seto Inland Sea, Japan. Grimes \& Bradbury (1992) also alluded to host-specificity of $V$. pelagica in northwestern Atlantic waters, although they did not discuss it in detail. In the Seto Inland Sea the apostome ciliate evidently prefers Paracalanus parvus s.l., Euterpina acutifrons, Corycaeus affinis, Calanus sinicus and other calanoids to Oithona spp. and Microsetella norvegica. The preference is not related to their body size, taxonomic position or feeding habits, although the cyclopoids Oithona spp. and the harpacticoid $M$. norvegica were much less prevalently infected. Infection occurred in calanoid, cyclopoid, harpacticoid and poecilostomatoid copepods of a wide range of body lengths (0.3 to $3 \mathrm{~mm}$ ). In addition, Euchaeta plana, Tortanus spp. and C. affinis are carnivores (Anraku \& Omori 1963, Gophen \& Harris 1981, Bailey \& Yen 1983, Ohtsuka 1991), while others essentially feed on small suspended particles and/or microzooplakters (Marshall \& Orr 1955, Anraku \& Omori 1963, Turner 1978, 1984a,b, Ohtsuka 1991, Ohtsuka \& Onbé 1991, Mauchline 1998, Ohtsuka et al. 1999). Although the reason for avoidance is as yet unclear, it may be that some chemical substances released from the copepods and/or, less likely, their swimming modes influence prevalence. Perhaps the fact that the dominant chaetognath Sagitta crassa avoids Oithona spp. for food (Nagasawa \& Marumo 1984) may be related. In the case of $M$. norvegica, the cuticle surface condition and/or its slender and rigid body may be a factor. The body structure may make it difficult for the trophont to enter the tissue from wounds. In addition, the elongated caudal setae of $M$. norvegica may hinder predation by the second host chaetognaths. Since swimming modes vary in pelagic copepods (Landry \& Fargerness 1988, Uchima \& Murano 1988, Yen 1988, Tsuda \& Miller 1998), these are less likely to be an important factor.

Although we did not directly examine health conditions of all individuals of the host copepods with phoronts of Vampyrophrya pelagica, these seem to have only limited influence on the host survival when hosts are uninjured. This can be inferred from their disguised attachment sites which do not overly restrict the host behaviour. However, injured hosts could certainly lead to death. Among individuals of the host copepods infected with phoronts, some were parasitized also by other endo- and ectoparasites such as dinoflagellates and epicaridean isopods (Ohtsuka et al. 2000, S.O. unpubl. data). If the apostome had attached to the host after infection of other parasites, it would have occurred regardless of health condition of the host. Experiments on the host specificity and selection of the apostome will be designed in the near future.

Drastic seasonal changes in prevalence of the phoronts were observed in the present study. Infection by phoronts was restricted mainly from July to February in the small-sized copepods (ca. $1 \mathrm{~mm}$ ), but not in the larger Calanus sinicus (ca. $3 \mathrm{~mm}$ ). Although $C$. sinicus was not always collected throughout the present survey, it occurs throughout the year in the Seto Inland Sea (as C. helgolandicus, Hirota 1961). The presence of phoronts also seems to be constant in this species (present study, S. Ohtsuka unpubl. data). Prevalence differed markedly in warm- and cold-water congeners of almost equal size: warm-water Acartia pacifica and $A$. erythraea vs. cold-water $A$. omorii; warm-water Centropages tenuiremis vs. cold-water C. abdominalis. These facts might suggest that tomite infection of pelagic copepods does not occur between March and June. In fact, turnover from the phoront to the tomite takes much longer at winter temperatures than at summer temperatures (K.Y. unpubl. data). On the other hand, Calanus sinicus is a long-lived species, in which its longevity is more than $140 \mathrm{~d}$ at a temperature in January to February $\left(9.9\right.$ to $\left.12.5^{\circ} \mathrm{C}\right)$ on the basis of Uye's (1988) equation: Longevity $=1334(T+0.7)^{-0.86}$ ( $T$ : temperature in ${ }^{\circ} \mathrm{C}$ ). It may be that $C$. sinicus with phoronts overwinters without molting, while other short-lived copepods such as Paracalanus parvus s.l. more frequently cast off discarding the phoronts (age at most 11 to $30 \mathrm{~d}$ : see Mauchline 1998, Table 56). In addition, since the dominant chaetognath Sagitta crassa preys mainly upon small-sized copepods such as Acartia omorii (as A. clausi) and Paracalanus crassirostris (as Parvocalanus c.) (Nagasawa \& Marumo 1984), C. sinicus may not be involved in the 2-host cycle sensu Grimes \& Bradbury (1992) in the Seto Inland Sea. In mid-summer, the attachment of phoronts on small-sized copepods may be re-established by tomites released from large-sized copepods such as $C$. sinicus with the rise in water temperature, and enhanced by the rapid increase in abundance of chaetognaths, that is, via the 2-host cycle.

To date we do not know to what extent the apostome ciliates depend on either the single host cycle or on the 2-host cycle in the field. It may be related to the abundance of copepod predators. What kinds of copepod predators other than chaetognaths can become second hosts? Hydrozoans and ctenophores are possible candidates (Grimes \& Bradbury 1992). Predatory copepods such as the Euchaetidae, Pontellidae, and Tortanidae appear not to become second hosts, on the basis of extensive gut content analyses (Ohtsuka 1991). Fish larvae also do not seem to be important as second 
hosts, partly because they only temporarily occur as plankton. The gut passage time of fry of Plecoglossus altivelis altivelis (Temminck \& Schlegel) is ca. $120 \mathrm{~min}$ (K.Y. unpubl. data), comparable to that of chaetognaths (in Sagitta crassa: 100 to 360 min: Feigenbaum 1991). However, our preliminary feeding experiment using fry of $P$. altivelis altivelis as a copepod predator revealed that the apostome phoronts failed to hatch in the guts and were totally digested during their passage through the fry gut. Therefore the phoronts appear to be intolerant of some fish fry digestive enzymes. Grimes \& Bradbury (1992) also found that no excystation occurred in the digestive systems of sea anemones and sea cucumbers after copepods with phoronts of Vampyrophrya pelagica were ingested. Predation by some fish and benthic invertebrates upon phorontinfected copepods may not be important in the life cycle of apostome ciliates.

\section{Parasite-host interactions}

Little attention has so far been paid by planktologists to the role of apostome ciliates in the marine ecosystem (Bradbury 1996). This is in contrast to oligotrich ciliates that have been studied intensively, and are suggested to play important roles in the microbial loop (Stoecker \& Capuzzo 1990). This may be partly because apostomes are essentially a parasitic form rather than a free-living one (Chatton \& Lwoff 1935, Grimes \& Bradbury 1992, present study). However, the histophagous feeding in apostome ciliates seems to be relevant to both grazing and detritus food chains considering their high prevalence on copepods and their direct influence on copepod predators. Their rapid consumption of copepod tissues soon after injury or predation and nutrient absorption before digestion by copepod predators may influence not only production of the hosts but also the formation, quality and quantity of the detritus matter originating from the hosts. Therefore apostomes may be directly involved in the trophodynamics and biochemical fluxes in the water column. Chatton \& Lwoff (1935) and Grimes \& Bradbury (1992) observed that planktonic and benthic invertebrate predators such as hydrozoans, ctenophores and chaetognaths were utilized as secondary hosts by apostome trophonts via ingested copepods. The apostome Vampyrophrya pelagica occurs on pelagic copepods on the coasts of both the North Atlantic (North Carolina, USA) and the North Pacific (Seto Inland Sea, Japan) (Grimes \& Bradbury 1992, present study). Phoronts of other apostome ciliates on pelagic copepods are found not only in shallow, but also deep waters (Chatton \& Lwoff 1935, Sewell 1951, Grimes \& Bradbury 1992, Ohtsuka et al. 2000, 2003, S. Ohtsuka unpubl. data). Apostomes infect many pelagic and benthic crustaceans such as ostracods, gammarids, isopods, caprellids, euphausiids, leptostracans, and decapods in addition to copepods (Chatton \& Lwoff 1935, Bradbury 1966, 1996, Kudo 1966, Lindley 1978, Capriulo \& Small 1986, Capriulo et al. 1991, Gómez-Gutiérrez et al. 2003). Capriulo et al. (1991) reported that in the Bering Sea the extremely high prevalence (up to $98 \%$ ) of an apostome endoparasite in euphausiids may lead to reduced growth and egg production, and even death. Recently Gómez-Gutiérrez et al. (2003) have discovered high densities of dead euphausiids on the sea floor between 550 and $220 \mathrm{~m}$ depth off the coast of Oregon, USA, which was caused by the infection of the parasitoid apostome Collinia sp., and implied that the parasite infection may have been one of major factors of mortality. This is contrast to histophagous apostomes which presumably have almost no influence on host mortality. Certain apostomes cause melanization in the gills and carapaces of many families of crabs (Chatton \& Lowff 1935, Bradbury 1996). Some apostomes infect other apostomes, actiniarians, ctenophores, cephalopods, and ophiuroids (Chatton \& Lwoff 1935, Bradbury 1966, Kudo 1966). Trophodynamic and pathological surveys on apostomes will be needed to understand the marine ecosystem more completely.

Acknowledgements. We express our sincere thanks to Dr. C. Busby and 4 anonymous referees for their critical reading of the manuscript. Thanks are due to Professor Emeritus Y. Shigenaka, Drs. T. Kosaka, K. Nagasawa and Y. Hanamura for their encouragement, and to Mr. S. Okabe for his cooperation at sea. This was in part supported by grant-in-aid from the Japan Society for the Promotion of Sciences (Nos. 14560151/16370039).

\section{LITERATURE CITED}

Anraku M, Omori M (1963) Preliminary survey of the relationship between feeding habits and the structure of the mouth parts of marine copepods. Limnol Oceanogr 8: 116-126

Bailey KM, Yen J (1983) Predation by a carnivorous marine copepod, Euchaeta elongata Esterly, on eggs and larvae of the Pacific hake, Merluccius productus. J Plankton Res 5: 71-82

Bradbury PC (1966) The life cycle and morphology of the apostome ciliate, Hyalophysa chattoni n. g., n. sp. J Protozool 13:209-225

Bradbury PC (1973) The fine structure of the cytostome of the apostomatous ciliate Hyalophysa chattoni. J Protozool 20: 405-414

Bradbury PC (1996) Pathogenic ciliates. In: Hausmann K, Bradbury PC (eds) Ciliates: cells as organisms. Gustav Fisher Verlag, Stuttgart, p 463-477

Cachon J, Cachon M (1987) Parasitic dinoflagellates. In: Taylor FJR (ed) The biology of dinoflagellates. Botanical monographs, Vol 21. Blackwell Scientific Publications, Oxford, p 571-610

Capriulo GM, Small EB (1986) Discovery of an apostome ciliate (Collinia beringensis n. sp.) endoparasitic in the Bering Sea euphausiid Thysanoessa inermis. Dis Aquat Org 1:141-146 
Capriulo GM, Pedone MJ, Small EB (1991) High apostome ciliate endoparasite infection rates found in the Bering Sea euphausiid Tysanoessa inermis. Mar Ecol Prog Ser 72:203-204

Chatton É, Lwoff A (1935) Les ciliés apostomes. I. Aperçu historique et général: étude monographique des generes et des espèces. Arch Zool Exp Gén 77:1-453

Chiba T (1956) Studies on the development and the systematics of Copepoda. J Shimonoseki College Fish 6:1-90 (in Japanese with English summary)

Chen QC, Zhang SZ (1965) The planktonic copepods of the Yellow Sea and the East China Sea. I. Calanoida. Stud Marina Sinica 7:20-131 (in Chinese with English abstract)

Chen QC, Zhang SZ, Zhu CS (1974) On planktonic copepods of the Yellow Sea and the East China Sea. II. Cyclopoida and Harpacticoida. Stud Marina Sinica 9:27-76 (in Chinese with English abstract)

Feigenbaum D (1991) Food and feeding behaviour. In: Bone Q, Kapp H, Pierrot-Bults AC (eds) The biology of chaetognaths. Oxford Science Publications, Oxford, p 45-54

Fernandez-Leborans G, Tato-Porta ML (2000) A review of the species of protozoan epibionts on crustaceans. I. Peritich ciliates. Crustaceana 73:643-683

Gómez-Gutiérrez J, Peterson WT, Robertis AD, Brodeur RD (2003) Mass mortality of krill caused by parasitoid ciliates. Science 301:339

Gophen M, Harris RP (1981) Visual predation by a marine cyclopoid copepod, Corycaeus anglicus. J Mar Biol Assoc UK 61:391-399

Grimes BH, Bradbury PC (1992) The biology of Vampyrophrya pelagica (Chatton \& Lwoff, 1930), a histophagous apostome ciliate associated with marine calanoid copepods. J Protozool 39:65-79

Hiromi J, Kadota S, Takano H (1985) Diatom infectation of marine copepods (review). Bull Tokai Reg Fish Res Lab $117: 37-46$

Hirota R (1961) Zooplankton investigations in the Bingo-nada region of the Setonaikai (Inland Sea of Japan). J Sci Hiroshima Univ Ser B Div 1 (Zool) 20:83-145

Hirota R (1979) Seasonal occurrence of zooplankton at a definite station off Mukaishima from July of 1976 to June of 1977. Publ Amakusa Mar Biol Lab Kyushu Univ 5:9-17

Ho JS, Perkins PS (1985) Symbionts of marine Copepoda: an overview. Bull Mar Sci 37:586-598

Ianora A, Mazzocchi MG, Scotto di Carlo B (1987) Impact of parasitism and intersexuality on mediterranean populations of Paracalanus parvus (Copepoda: Calanoida). Dis Aquat Org 3:29-36

Kado Y (1957) The seasoanl change of the chaetognath and pelagic copepod fauna of Hiroshima Bay in the Inland Sea of Japan, with special reference to the appearance of oceanic species. J Sci Hiroshima Univ Ser B Div 1 (Zool) 17:121-129

Kimmerer WJ, McKinnon AD (1990) High mortality in a copepod population caused by a parasitic dinoflagellate. Mar Biol 107:449-452

Kudo RR (1966) Protozoology, 5th edn. Charles C Thomas Publisher, Springfield, IL

Landry MR \& Fargerness VL (1988) Behavioural and morphological influences on predatory interactions among marine copepods. Bull Mar Sci 43:509-529

Lindley JA (1978) Continuous plankton records: the occurrence of apostome ciliates (Protozoa) on Euphausiacea in the North Atlantic Ocean and North Sea. Mar Biol 46: 131-136

Marshall SM, Orr AP (1955) The biology of a marine copepod. Oliver \& Boyd, Edinburgh

Mauchline (1998) The biology of calanoid copepods. Adv Mar Biol 33:1-710

Nagasawa S (1986) The peritrich ciliate Zoothamnium attached to the copepod Centropages abdominalis in Tokyo Bay. Bull Mar Sci 38:553-558

Nagasawa S, Marumo R (1984) Feeding habits and copulation of the chaetognath Sagitta crassa. La Mer 22:8-14

Nishida S (1985) Taxonomy and distribution of the family Oithonidae (Copepoda, Cyclopoida) in the Pacific and Indian Ocean. Bull Ocean Res Inst, Univ Tokyo 20:1-167

Nishida S (1997) The family Oithonidae. In: Chihara M, Murano M (eds) An illustrated guide to marine plankton in Japan. Tokai University Press, Tokyo, p 935-951

Ohtsuka S (1991) Structure and function of the mouthparts of calanoid copepods of the Seto Inland Sea and its environs, with special reference to their in-situ feeding habits. Doctoral thesis, University of Tokyo

Ohtsuka S, Onbé T (1991) Relationship between mouthpart structures and in situ feeding habits of species of the family Pontellidae (Copepoda: Calanoida). Mar Biol 111: 213-225

Ohtsuka S, Ohtani S, Seike Y, Kunii H, Nishida S (1999) Feeding habits of zooplankton, in particular, copepods in Lake Naka-umi. Laguna 6:89-105 (in Japanese with English abstract)

Ohtsuka S, Nagasawa K, Gejima K (2000) Review of parasites of marine zooplankton. Bull Plankton Soc Jpn 47:1-16 (in Japanese with English abstract)

Ohtsuka S, Boxshall GA, Fosshagen A (2003) A new species of Neoscolecithrix (Crustacea; Copepoda; Calanoida) from off Okinawa, southwestern Japan, with comments on the generic position in the superfamily Clausocalanoidea. Bull Natn Sci Mus (Tokyo) 29:53-63

Sewell RBS (1951) The epibionts and parasites of the planktonic Copepoda of the Arabian Sea. Sci Rep John Murray Exped 9:255-394

Shields JD (1994) The parasitic dinoflagellates of marine crustaceans. Annu Rev Fish Dis 4:241-271

Steuer A (1932) Copepoda 6: Pleuromamma Giesbr. 1898 der Deutschen Tiefsee Expedition. Wiss Ergeb Dt TiefseeExped 'Valdivia' 1898-1899 24:1-119

Stoecker DK, Capuzzo JM (1990) Predation on protozoa: its importance to zooplantkon (review). J Plankton Res 12: 891-908

Théodoridès J (1989) Parasitology of marine zooplankton. Adv Mar Biol 25:117-177

Tsuda A, Miller CB (1998) Mate-finding behaviour in Calanus marshallae Frost. Phil Trans R Soc Lond B 353:713-720

Turner JT (1978) Scanning electron microscope investigations of feeding habits and mouthpart structures of three species of copepods of the family Pontellidae. Bull Mar Sci 28: $487-500$

Turner JT (1984a) Zooplankton feeding ecology: contents of fecal pellets of the copepods Eucalanus pileatus and Paracalanus quasimodo from continental shelf waters of the Gulf of Mexico. Mar Ecol Prog Ser 15:27-46

Turner JT (1984b) Zooplankton feeding ecology: contents of fecal pellets of the copepods Acartia tonsa and Labidocera aestiva from continental shelf waters near the mouth of Mississippi River. PSZNI Mar Ecol 5:265-282

Uchima M, Murano M (1988) Mating behaviour of the marine copepod Oithona davisae. Mar Biol 99:39-45

Uye S (1988) Temperature-dependent development and growth of Calanus sinicus (Copepoda: Calanoida) in the laboratory. Hydrobiologia 167/168:285-293

Yagiu R, Shigenaka Y (1965) Electron microscopy of the ectoplasm and the proboscis in Didinium nasutum. J Protozool 12:363-381

Yen J (1988) Directionality and swimming speeds in predatorprey and male-female interactions of Euchaeta rimana, a subtropical marine copepod. Bull Mar Sci 43:395-403 